\title{
A Shadow of Truth: Honor Klein in Iris Murdoch's A Severed Head
}

\author{
Barbora Kašpárková \\ Masaryk University, Brno, Czech Republic
}

Iris Murdoch's novel A Severed Head (1961) is an example of convoluted relationships that may appear hilarious upon superficial analysis. A close reading, however, reveals the suffering triggered by the behaviour of the central characters. The most mysterious female protagonist, the sexually ambivalent Honor Klein, deploys a wide range of possible interpretations. Honor's powerful figure is like an axis around which the rest of the characters rotate and without whom the plot would fall apart. The question is, nonetheless, if she is a real figure or not. This paper argues that this pivotal character is not a real person but a dreamy and ghostly concentration of elements in relation to the protagonist Martin Lynch-Gibbon. Honor Klein is a force, is suspicion, and fear, and seems to be an external projection of Martin's subconscious imaginary fears and trauma. She has a similar narrative function as Shakespeare's ghosts in, e.g., Macbeth, Hamlet and Julius Caesar.

\section{Keywords}

Iris Murdoch; A Severed Head; Honor Klein; Martin Lynch-Gibbon; psychoanalysis; spectre; Hamlet

The Anglo-Irish novelist and philosopher Iris Murdoch was captivated by the labyrinthine structure of the human mind. Her novels are about freedom, love, and evil but above all how to become good by being free. This was one of the questions she was more preoccupied with both in her moral philosophy and her novels: how imperfect individuals are. Murdoch once revealed about her novel writing, "I want to talk about ordinary life and what things are like and people are like, and to create characters who are real, free characters" (Dooley 29). A reader of her novels is repeatedly confronted with various traumatic experiences undergone by characters who are blinded by sexual obsession, ignorance, lies, egotism, and desire. There is also the inclination to repeat the same mistakes: characters are trapped in a maelstrom of sex, love and 
sentimental confusion. Their trauma is often caused by sudden anagnorisis, and that knowledge leads to the main characters' confrontations with something they were not aware of or did not want to see.

Honor Klein is one of the most fascinating, mysterious and uncanny character creations of Iris Murdoch. ${ }^{1}$ Honor Klein borders between attraction and repulsion and is one of Murdoch's powerful enchanter figures. It could be argued that for her undisputable force and power she attracts more than repulses. But that disturbing strangeness could be only a literary phenomenon, defamiliarization - ostranenie. She is an androgynous figure and as Leeson explains, Murdoch:

promotes her enchanter figures as dis-endengered in order to make them both uncanny - for both the reader and the other related characters - and hugely unpredictable. Without a fixed gender type they are able to inhabit both male and female personas and by doing so direct the course of action that others may take. ("The Engendered and Dis-engendered Other in Iris Murdoch's Early Fiction", 116)

The primary focus of this paper is an exploration of the powerful and uncanny character, Honor Klein, who despite Murdoch's doubts about Freudian psychoanalysis represents an external projection of the main protagonist's (Martin Lynch-Gibbon) subconscious imaginary fears, and trauma. Freud's influence on this story has been examined several times (Leeson 2009, Nicol 2004, Turner 1994, Byatt 1965), but only Leeson in a way suggests that Honor seems to be a projection of "the embodiment of the darker side of Freudian psychoanalysis" (66), and Nicol proposes that the aforementioned character is "a demonic icon" (128). The possibility that Honor Klein does not have a real physical existence beyond Martin's mind, is maintained in this paper.

Murdoch's early novel $A$ Severed Head (1961) represents an apt example of human fragility. It is one of her "closed novels" "where one is more in a world of patterns and artifice, or coincidence and arrangements" as Murdoch explains (Dooley 22). It also reflects the atmosphere of the sexually liberated 1960 , portrayed in a certain way by the frenetic swapping of partners. The novel caused some scandalous reactions for its incest scene, but the liberal atmosphere of the Sixties helped the acceptance, with delight, of the work. The narrative can be interpreted as a journey from illusion to reality or, more simply, the search for truth, goodness, and freedom through love; ideas that can be found in Plato's Symposium. Some critics suggest that the novel is 
just an "intensely stylised Restoration comedies of manners" (Conradi 434), a "parody of psychoanalysis" (Franková 11), "a playfully Freudian novel" (Johnson 17), "a social satire or a 'Freudian comedy"” (Nicol 113). Though it is true that there is a grotesque dimension in the convolution of love affairs in A Severed Head, as in a bourgeois comedy of errors, a dual reading is possible, mixing the sarcastic with the serious. Thus, Murdoch's novel can be read in this lateral way, trying not to reduce or simplify the complications and sexual ambiguities.

While various critics see Freud's influence on Murdoch's A Severed Head, she as a moral philosopher did not fully recognize psychoanalysis. One of Murdoch's reasons is that "the analyst had illicit power which he might abuse and abuse sexually; only a 'saint' could be a therapist" (qtd. in Conradi 494), which is the case with Palmer Anderson, an analyst, who seduces the central character's wife, Antonia. In her philosophical book The Sovereignty of Good (1971), she claims that "psychoanalysis is a muddled embryonic science" (Murdoch 26), but her criticism is also palpable in her Metaphysics as a Guide to Morals (MGM):

The familiar conception of 'analysis' conveys a misleading idea of a minute scientific scrutiny of the human mind: an area in which it is difficult, except at a superficial level, to distinguish illusion from truth and certainly difficult to do so without the introduction of moral concepts. (22)

She could not entirely agree with psychoanalysis, as her idea of becoming selfless was opposed to becoming self-aware ${ }^{2}$, and psychoanalytical treatment focuses on an inner self-tracing of past suppressed traumas. That is the reason why she embraced Simone Weil's concept of attention to the Other that is missing in the story. Leeson confirms her complicated stance on Freud's psychoanalysis asserting that "Murdoch wishes individuals to attend to others in order to free themselves from their egotistical desires" and adds that "the problems of neurosis will not be cured by a general theory of psychoanalysis" (63). Nevertheless, in The Sovereignty of Good, she makes clear that "Freud made an important discovery about the human mind and that he remains still the greatest scientist in the field $[\ldots]$ he presents us with a realistic and detailed picture of the fallen man" (50). Furthermore, Murdoch declared, that unlike Sartre, she does not deny Freud's theory completely. Thus it can be argued that she discussed it in the situations and conflicts portrayed in her novels because even if she felt that philosophy had to be separated from science and 
literature, it proved not to be that easy as she claims that "briefly put, our picture of ourselves has become too grand, we have isolated, and identified ourselves with, an unrealistic conception of will, we have lost a vision of reality separate from ourselves, and we have no adequate conception of original sin" (Existentialists and Mystics 338). This criticism matches mostly all the characters in the novel, namely Martin, Palmer, and Antonia for their ego drives them away from seeing others.

Honor Klein, who sheds light on the secrets of the aforementioned characters, is the most ambiguous figure of the narrative and has been given a considerable number of attributes and a wide range of possible interpretations. She is a dark demonic figure that evokes awe in others by both her behaviour and appearance. She is the most powerful female protagonist possessing "uncanny talents and qualities", as Miranda Seymour states in the Introduction to the 2001 Vintage edition (vii). Second, for Murdoch, Honor Klein and a strong male character Mischa Fox (The Flight from the Enchanter) are - note the significant allusion to the supernatural - "gods who are deified by their surrounding followers" (Dooley 24). Third, and the latest idea can be found in Living on Paper: Letters from Iris Murdoch 1934-1995, it is suggested that Honor Klein represents a blend of both her intimate friends, Brigit Brophy and Margaret Hubbard, turbulent relationships that significantly influenced her life. An intimate relationship with Hubbard was behind her resignation from her academic post at St Anne's College as their affair started to turn into a scandal - even her marriage might have been jeopardized (170). Importantly for this essay, Brophy frequently conveyed psychoanalytical ideas to Murdoch, and she did not refute them. Another suggested autobiographical possibility may be that it is Murdoch herself, as she also claimed that the novel is "a myth and more organically connected with herself and that it is full of her" (Dooley 7). Murdoch was a highly unconventional person in terms of her open sexuality and the sincerity with which she addressed her friends and acquaintances, like her character Honor Klein. Finally, Honor Klein's name may also bear a connection with Melanie Klein, an idea that was dismissed by Murdoch in one of her letters to Brophy, "About Klein, no connection in my mind Melanie-Honor, so far as I know. I had no M. Klein concepts prior to the ones you gave me. (A psychoanalysed friend was very cross about the name as he thought I was somehow getting at Melanie. They are very touchy)" (Murdoch 241). However, this idea cannot be dismissed, taking into consideration the emphasis on psychoanalysis in the story and the fact she was acquainted with Melanie Klein's work. It would be highly 
speculative to assert Murdoch had Klein's theory of Object Relations in her mind when constructing the central characters, so this idea is not a focus of this paper.

Going beyond the biographical and anecdotal, the crucial question in this paper is if she is a real figure in the narrative or if she is just the narrator's illusion or an inner voice that reveals to him his suppressed knowledge. It could be a projection of an author's sujet supposé savoir, or a spectral projection of Martin's unconscious conflicts and his desire to know.

From a Freudian perspective, Honor Klein could be read as Martin's Superego, the unconscious agency that disciplines and punishes. She tells him how he should act in his blindness and scorns him as a way of punishment; she also reveals him the truth, not only his but of others. To accept reality and to decide which way to choose is the most demanding task for Martin. This is not the way the Unconscious works; there are not various "departments" (Ego, Superego, Id) functioning independently for the sake of intellectual clarity and tranquillity. Each human mind is structured differently, and the various agencies interact and blend. It must be stressed, that in this paper the objective is not "psychoanalyzing" Martin, or Murdoch. There is no "transference" in a text, no free-association of signifiers. There is in the novel a subtle reflection on psychoanalysis, knowledge, desire and the unconscious. Honor Klein is more than a Superego. She is a spectral projection of Martin's confrontation with trauma, opening spaces of his subjectivity, of his self, still closed to knowledge, blocking him and his life and condemning him to repetition, that is, to death in life.

The hypothesis of Honor Klein being a "haunting spectre" is vital to clarify, from a psychoanalytical perspective. The expression is not meant to imagine the phantasm from gothic stories but the ghost that externalizes our internal fears and are subjects of psychoanalysis. "The real specter is reality's sign", and "the presence of a specter is inevitably marked by the trace of absence" (Mazin). It supplements something or substitutes somebody. Honor Klein's role can be understood as the emergence of Martin's absence of truth (he is an unreliable narrator and has a secret), and thus, she is to make him see the reality. Spectres connect the past with the present, and Martin narrates the story in retrospect. His primary interest is military history; Honor is an anthropologist and her brother Palmer a psychoanalyst, all of them are interested in the past.

Speaking of spectres, Shakespeare's ghosts cannot be ignored for Murdoch was passionate about his writing. She admired his plays for being "showings" 
and that they are "criticisms" of vast areas of human life" (Metaphysics as a Guide to Morals 115). Under his influence, she constructs human relationships but without didactic intentions. Klein's role may be viewed as Hamlet's spectre of his father. Similarly, Martin is incapable of cleaning his honour, of acting and following Honor Klein's superegoic instructions to get his wife back and face Palmer's superiority. But his incapability to act may be caused as well by his unconscious feelings of guilt and anxiety. Still, the case with Hamlet is slightly different as he thinks and plans, whereas Martin seems to be paralyzed:

Hamlet is paralyzed by the obsessive ghost. Key to his problem is the undecidability represented by the introjected oedipal relations: you should be like your father, but you have no right to be like him. Why is Hamlet unable to revenge his father's death? Because he must revenge himself upon one who has taken his - oedipal - place. He must revenge himself upon himself, upon his other, upon himself-at-some-other-place. This is the reason why his hatred takes the form of self-reproach. (Mazin)

Martin's feelings of guilt and anxiety are caused by the fact that he cheats on his wife and causes tremendous mental pain to his mistress Georgie by making her abort their child and giving her empty promises, no wonder he is paralyzed and haunted by dreams, "It had all been quite uncannily painless. I was left with a sense of not having suffered enough. Only sometimes in dreams did I experience certain horrors, glimpses of a punishment which would perhaps find its hour" (A Severed Head 10). ${ }^{3}$

Martin is described as "an intelligent, priggish, forty-one-year-old wine merchant with a frustrated interest in military history which he reads and, a little, writes" (Conradi 434), tinted with a degenerate innocence, a description that can have a "positive" dimension for our argumentation. He has a psychological attachment to war and conflict as well as a relationship with writing - and the intellectual work and "otherness" it implies. Early in the story, we learn that his wife Antonia has left him with their close friend and psychoanalyst Palmer Anderson, which leaves Martin devasted but ironically, he has a young mistress Georgie to whom he constantly lies about going to leave his wife. Martin's wife Antonia is older and represents a mother-figure. The reader is familiar with Martin's attachment to his deceased mother; thus in Mazin's words, it can be stated that "the super-ego is the ever-living spectrum of the parents' traits, their specter, an agency representing the parental voice" (Mazin). Therefore, in a certain way, we can assume that Honor Klein represents the mother's 
voice, an invisible supervising gaze from the past but also the future as she shows him the way to change the current situation. This superego dimension of Honor Klein is there, but it is not the main dimension, for the character creation is more complex. Martin's attachment to his mother is evoked in him by his brother Alexander and by the house, Rembers, where they were raised and grew up:

especially when I saw him at Rembers, that although the form of his face perfectly recalled my father, its spirit and animation perfectly recalled my mother. ... I recalled her clearly, with a sad shudder of memory, and with that particular painful guilty thrilling sense of being both stifled and protected with which a return to my old home always afflicted me; and now it was as if my pain for Antonia had become the same pain. ... Perhaps indeed it had always been the same pain (38).

The signifier "Rembers" evokes "remembers", and for psychoanalysis, memory is oblivion/forgetting as well or in Freud's observations "the memory's disinclination to remembering anything which is connected with feelings of unpleasure and the reproduction of which would renew the unpleasure" (Freud 103). For Martin, the house recalls the memories of his dead mother. Martin's impossibility to leave Antonia is caused by the mother fixation that is also suggested by Palmer from a psychoanalyst's point of view: "You have been a child to Antonia and she a mother to you, and that has kept you both spiritually speaking at a standstill. But you will grow up" (27). Palmer is taking advantage of his position over Martin but also over Antonia. In his condescending and humiliating arrogance, Palmer is a real parody of the ethos of the analyst as well as the procedure of analysis. He does not hesitate to demonstrate who rules in this new situation. Palmer's behaviour, misusing his knowledge of psychoanalysis, is what Murdoch criticized. Palmer consciously manipulates Martin to regain Antonia, disguising himself as an erudite therapist, while abusing his role.

The problem with Palmer seems to be even more perverse because what might prevent Martin from acting is his latent attraction to Palmer. A jealous person, according to Freud, can be a latent homosexual (Complete Works 1923). Considering Murdoch's bisexuality in the analysis cannot by itself explain the autonomy of the text. The incest part confronts Martin with trauma in a primordial sexual scene, a kind of a return of the repressed. This scene can be Martin's suppressed gay fantasy. Thus, the role of Honor Klein as 
Palmer's half-sister shows him the mirror of his unconscious mind, his sexual desire. In a metaphorical condensation, Palmer represents a Freudian father (surely, if the reader considers the second time Martin sees him in bed, then with Antonia - a clear mother-figure). He tells Martin: "you saw what you expected to see" (136). In this incest scene, even without Martin's reaction, Palmer crumbles - in a way, it is like the former's revenge. This shocking revelation consequently leads to Antonia and Palmer's breaking up. Palmer as a psychoanalyst fails to restore his relationship with Antonia; he loses his power and Martin gets a step before him, but not for long. It is extraordinary how Murdoch shocks the reader but does not further deal with such a social taboo as incest is and thus makes the reader digest it and move forward without any further explanation.

Martin meets Honor Klein when he is sent by Antonia to pick her up at the station. He describes the atmosphere at the station as "the Inferno", people looking ill, the persistent smell of sulfur in the air, low visibility, and chaos. This description may reflect Martin's state of mind as he starts to develop a post-traumatic nervous breakdown. Murdoch creates the gothic atmosphere of the story by employing thick fog and the ubiquitous odour of sulphur from the moment Antonia reveals her love affair with Palmer. It frequently rains, and the light comes only for a few moments. The mood of the narrative underlines his traumatic feelings and sexual repression and his incapability to accept the loss. Taking into consideration that Martin sees Honor in the most difficult situations, then her role in the narrative can be understood as his other self who tries to lead him away from the borderline of fantasy to reality, from the darkness to the light. In his sudden solitude, he urgently needs a saviour, a guide who would lead him out of hell and show him how to reach and accept the truth. To support the idea of Honor Klein as a kind of hallucination, it is important to mention that Martin does not perceive her as a human being when he sees her: "I don't care what this object thinks of me" (54). Honor Klein has a very piercing uncanny gaze that makes one uncomfortable and is emphasized multiple times in the story. The gaze from a psychoanalytical perspective is "the essence of spectrality itself" (Mazin). She painfully reminds him of what is going on, and the need for confronting the problems, which Martin avoids. There are many instances when her influence lessens his emasculation. For instance in Palmer's house, it is the image of a samurai sword that hangs on the wall above Honor's head when Martin must face the couple (Palmer and Antonia). Martin perceives Honor "like some insolent and powerful captain" (29). The words "powerful" 
and "captain" symbolize Honor Klein's role in his precarious journey. Martin is oscillating between the sensation of power and the total despair of a victim throughout the story. The behaviour of Palmer and Antonia does not help him either - they treat him like a child: "You see", said Palmer, "it is not at all our idea that you should leave us. In a strange and rather wonderful way we can't do without you. We shall hold on to you, we shall look after you. You'll see" (29). At this point, Martin resigns himself from ever getting Antonia back as he understands he is being manipulated and has gained the position of a fallen man.

While Martin sinks more into his mental turmoil, Honor Klein tightens her grip on him. When on his own in the house, Honor keeps provoking him to action by giving him direct questions: "Do you think they are doing the right thing?" (61); "As you must know perfectly well you could get your wife back if you wanted her even now. They look to you for help" (62). These irritating questions are the reminder that there may be a solution to regain his power but Martin, confused, tries to escape from the gnawing thoughts that are driving him crazy, but Honor does not let him: "You are a violent man, Mr LynchGibbon. You cannot get away with this intimacy with your wife's seducer". His primitive, violent self is becoming stronger as Honor changes in his eyes into "something black and untouchable" (63). She lucidly continues:

Everything in this life has to be paid for, and love too has to be paid for. ... I believe you love my brother. But you do him no good by letting him off. He wants, he needs, your harshness, your criticism, even your violence. Sooner or later you will have to become a centaur and kick your way out. (63)

Martin is inert and reluctant to understand: "I don't imagine that you ever let people off, do you, Dr Klein?" (63). She pins him with her fierce look and utters: "With me people pay as they earn" (63). The (inner) conversations usually result in Martin's attempts to change things but, ironically, in a moment when his secret can be discovered by his wife, he panics. His fear is so strong that he is again confronted with the spectre who makes him feel guilty for not having told the truth yet by "a steady tense meditative gaze" (63). Soon after the affair is revealed, Martin, devastated and astonished, faces how sadistically Antonia and Palmer treat him like a child for causing so much pain to her. As Martin never meant to tell the truth, and hurting both the women, its revelation gets him into a deeper muddle. Consequently, Martin 
becomes even more powerless, but he is entering yet another crucial point on his journey through hell to purgatory.

Martin deals with the situation by drinking, in fact, we never see him eating, only drinking whisky or wine. Murdoch's characters often drink alcohol that deepens their frustrations, and as, Lily in The Book and the Brotherhood advocates: "Alcohol can open the dark gates of the unconscious" (203). The only moment when he looks for something to eat is at the end of his journey. This fact may be important since Martin may constantly be under the influence of alcohol, which blurs his perception, plunging him into a dreamy state. When he meets Honor again, he utters: "You didn't waste much time in having me brought to justice" (94). Honor's face mirrors his state of mind: weariness, despair, and resignation. He confesses his weakness and fear: "I am a broken reed after all" (94). Murdoch effectively depicts the termination of both the relationships, with Antonia and Georgie, by the silent act of Honor gracefully cutting the napkins in two halves with the samurai sword. The katana is in a sense the realization of the need to accept castration as part of life, as well as a phallic symbol of masculine power bestowed by this godly and empowering Diotima: Honor Klein.

Even though Martin remains powerless, he still dominates Georgie. Georgie is a young university lecturer who is very much in love with Martin, who in turn gives her empty promises. She offers a striking difference when compared to his wife, Antonia. Georgie offers him liberation and importantly gives him a feeling of superiority. He gives Georgie various posh presents that Antonia would never accept and she controls every single thing in their marriage. Georgie represents the prime victim of all the characters. From a moral point of view, she surely cannot be taken as a "saint" but is the only figure whose passivity and pain leads to a suicide attempt. To call for Martin's attention and draw him out of his inward confused world where she is ignored, she starts to date his brother Alexander. His brother who is a marginal character is in fact in power throughout the story (he and Antonia have been lovers for ages). Martin, though he suffers, takes it as a good decision to make his life easier. So, it is for his ignorance and lack of empathy that Georgie gives up and decides to die. Before the attempt, she sends him a parcel, her hair. Murdoch plays with the symbol of a severed head throughout the story, and Georgie is, figuratively speaking, the first to lose her head physically. When Martin finds Georgie unconscious, he recalls she gave him signals, but he did not hear or see anything due to his egotism: "Indeed, there was so much 
I did not know, had not cared to know. [...] I had enjoyed but never had to pay" (175-176). Nevertheless, he does not feel guilty, which is also reflected in Honor's apparition in the room, "I thought she is pitiless. Then I thought, so am I" (176). Murdoch always describes her as a dark figure, looking more like death. Martin observes "the line of her mouth dead straight between the curving lips, and narrow eyes black" (177). She stays a static character until the end of the narrative. Unlike Martin, Honor can touch the body that seems repulsive to him, but he finally touches her as well:

I drew my finger down her thigh. I could feel the soft warm leg through the material. But what I felt more, [...], was the shiver of connexion between Honor's hand and mine; and I remembered our two hands almost touching on the blade of the Samurai sword. (177)

Martin realizes his sexual power again which is somewhat perverse regarding the whole dramatic situation. Murdoch portrays here how he still has not fully or genuinely regretted his deeds. Nonetheless, his mental turmoil is somehow calmer, which is probably caused by his selfish awareness that he does not feel any desire for Georgie, nor Antonia.

After Georgie is released from the hospital, it is Palmer who tries to regain the power over Martin. Murdoch again emphasizes the abusive power of the analyst by Palmer taking advantage of the entire situation when he gets hold of Georgie, who needs psychological treatment. Georgie never ceases to be a victim in the story as she passively accepts Palmer's offer to leave with him to America. Palmer, after being emasculated by the revelation of an incestuous relationship with Honor, decides to return to the USA as Martin lets him believe he would make it public, but he never would. Martin at this stage feels it is all over and that he sees both Palmer and Honor (who leaves with him) for the last time.

Martin's attachment to Honor is so strong that he cannot let her go, but she grounds him by saying: "Your love for me does not inhabit the real world. ... Because of what I am and because of what you saw I am a terrible object of fascination for you" (185). Martin returns to what he wanted back, to life with Antonia, his mother-figure, as he needs her to comfort him. Murdoch moves the plot by yet another moment of anagnorisis, with farcical overtones, when Antonia reveals her love affair with Martin's brother Alexander and their plan to be finally married after so many years of their secret liaison. Murdoch plays 
with the frequent expression "knowledge" which is hidden but is supposed to be known. It is seen in the relationship with Alexander. All the taboos have been revealed, but the characters feel hardly any regrets. Martin learns that his life with Antonia was practically made up when she calls him "a dreamer": "You like to dream along without facing things. Well, you must face things now. And stop being so sorry for yourself" (192), which is a paradox considering Antonia's behaviour has been far from what she expects from Martin.

Murdoch's depiction of human relations of power is quite dynamic and unstable throughout the narrative, depending on the secrets that have come to light. Thus, Martin again sinks to the bottom. Practically all except him and Georgie are winners, freed by egotism, seeking their pleasure and desire. The same flaws got Martin where he is now. He is at the end of his purgatory journey, alone, full of pain: "I sat thus for a long time surrendered to grief and to the physical pain which is the mark of a true emotion" (205). It only marks his former numbness and how difficult it is to realize the taste of reality.

The textual play with light and darkness at the end of the story is striking. Murdoch surprises the reader by Honor Klein coming back to seek Martin. She stands outside in semi-darkness, and Martin "lets her follow him in towards the light" but keeps a barrier (a camp bed) between them (205), "I let myself really see her now" (206), which underlies the problem of blindness as one of the major themes of the novel. The words to see and to know are visibly pointed out by Murdoch in the final dialogue between Martin and his apparition in a different tone, from anxious to conciliatory. Martin becomes a survivor, but does he? He pictures himself as both an audience and an actor of a drama with not exactly a happy ending but with hopes to forget and start again:

I said, 'We have lived together in a dream up to now. When we awake will we find each other still?'

I came round the bed and stood near to her. I worshipped her closeness. I said 'Well, we must hold hands tightly and hope that we can keep hold of each other through the dream and out into the waking world'.

As she still would not speak I said, 'Could we be happy?'

She said, 'This has nothing to do with happiness, nothing whatever'.

That was true. I took in the promise of her words. I said, 'I wonder if I shall survive it.'

She said, smiling splendidly, 'You must take your chance!'

I gave her back the bright light of the smile, now softening at last out of irony. 'So must you, my dear!' (208) 
Martin's conversation with Honor seems to indicate that he still lives in an illusion, unable to digest and understand his finished relationship with Antonia. This unhealthy mother-fixation keeps him trapped in his shattered mental state.

Murdoch's purpose is to draw attention to frequent human incorrigibility and egocentrism, how painful it is to deal with loss, trauma, and repetition. The novel is a narrative of a personal inner confrontation. Therefore, Honor Klein can be perceived as an external projection of Martin's subconscious fears and traumas. She may be only a "phantasm", confronting him with veiled and suppressed knowledge, giving him, at the end of the narrative, the power to overcome a series of failed relationships, but without any promises.

\section{Notes}

1. This paper is based on three different unpublished works about A Severed Head presented at conferences: "A Shadow of Truth: Honor Klein in Iris Murdoch's A Severed Head" (Eighth International Iris Murdoch Conference: Gender and Trauma, Chichester, UK, 1-2 Sept. 2017); "Iris Murdoch: Decapitating as Spiritual Exercise in A Severed Head" (Archives and Afterlife - The $7^{\text {th }}$ International Conference on Iris Murdoch, Kingston University, 12-13 Sept. 2014, Surrey, UK); "Anagnorisis as a Guide to Morals" (Salzburg Easter School 2017. Recognition: Continuity / Discontinuity, 8-17 April 2017).

2. This refers to a phrase in the Metaphysics as a Guide to Morals, and the influence of Simone Weil (see White 68-70).

3. From this point on, when quoting A Severed Head (Murdoch, 2001), reference will be only to the page number.

\section{Works Cited}

Conradi, Peter. Iris Murdoch: A Life. London: HarperCollins, 2002. Print. Dooley, Gillian (ed.). From a Tiny Corner in the House of Fiction: Conversations with Iris Murdoch. Columbia: University of South Carolina Press, 2003. Print.

Evans, Dylan. An Introductory Dictionary of Lacanian Psychoanalysis. London: Routledge, 1996. Print.

Franková, Milada. Human Relationships in the Novels of Iris Murdoch. Brno: Masarykova Univerzita v Brně, 1995. Print.

Freud, Sigmund. "Certain Neurotic Mechanisms in Jealousy, Paranoia and Homosexuality." International fournal of Psycho-Analysis. 1923: 4: 1-10. Print. ---. Introductory Lectures on Psychoanalysis. Harmondsworth: Penguin Books, 1991. Print. 
Johnson, Deborah. Iris Murdoch. Bloomington: Indiana University Press, 1987. Print.

Leeson, Miles. "Iris Murdoch's A Severed Head A Revision of Ideas: Freud and Nietzsche." The McNeese Review, vol. 47. 2009: 6o-78. Web. Accessed 8 February 2019. www.academia.edu/777075/Iris_Murdoch_s_A_Severed_ Head_A_Revision_of_Ideas_Freud_and_Nietzsche.

Mazin, Victor. "Specters of Freud." Trans. by Olga Serebryany and Peter Serebryany. European fournal of Psychoanalysis, vol. 19. 2004: n.pag. Web. Accessed 3 December 2018. http://www.journal-psychoanalysis.eu/spectersof-freud/.

Murdoch, Iris. Existentialists and Mystics: Writings on Philosophy and Literature. Ed. Peter J. Conradi. Harmondsworth: Penguin, 1999. Print.

---. The Book and The Brotherhood. Harmondsworth: Penguin Books, 1988. Print.

--. Living on Paper: Letters from Iris Murdoch 1934-1995. Eds. Avril Horner and Anne Rowe. London: Chatto \& Windus, 2015. Print.

---. Metaphysics as a Guide to Morals. London: Vintage, 2003. Print.

--.. A Severed Head. London: Vintage, 2001. Print.

---. The Sovereignty of Good. London: Routledge, 2006. Print.

Nicol, Bran. Iris Murdoch The Retrospective Fiction. Basingstoke: Palgrave Macmillan, 2004. Print.

White, Frances. Becoming Iris Murdoch. London: Kingston University Press, 2014. Print.

BARBORA KAŠPÁRKOVÁ is a Ph.D. student in the programme Literatures in English at the Department of English and American Studies, Faculty of Arts, Masaryk University and an Instructor in the Department of English Language and Literature, Faculty of Education, Masaryk University, Brno. In her research, she focuses on the literary and philosophical work of Iris Murdoch especially on ethics and human relations in her novels. She teaches courses in English Literature ( $19^{\text {th }}$ and $20^{\text {th }}$ century), Critical Reading and Practical Language.

kasparkova2015@gmail.com 